\title{
An evaluation of the emerging interventions against Respiratory Syncytial Virus (RSV)- associated acute lower respiratory infections in children
}

Harish Nair ${ }^{1,2+}$, Vasundhara R Verma ${ }^{1 \dagger}$, Evropi Theodoratou ${ }^{1}$, Lina Zgaga ${ }^{1}$, Tanvir Huda ${ }^{3}$, Eric AF Simões ${ }^{4}$, Peter F Wright ${ }^{5}$, Igor Rudan ${ }^{1,6+}$, Harry Campbell ${ }^{1 *+}$

\begin{abstract}
Background: Respiratory Syncytial Virus (RSV) is the leading cause of acute lower respiratory infections (ALRI) in children. It is estimated to cause approximately 33.8 million new episodes of ALRI in children annually, 96\% of these occurring in developing countries. It is also estimated to result in about 53,000 to 199,000 deaths annually in young children. Currently there are several vaccine and immunoprophylaxis candidates against RSV in the developmental phase targeting active and passive immunization.

Methods: We used a modified CHNRI methodology for setting priorities in health research investments. This was done in two stages. In Stage I, we systematically reviewed the literature related to emerging vaccines against RSV relevant to 12 criteria of interest. In Stage II, we conducted an expert opinion exercise by inviting 20 experts (leading basic scientists, international public health researchers, international policy makers and representatives of pharmaceutical companies). The policy makers and industry representatives accepted our invitation on the condition of anonymity, due to the sensitive nature of their involvement in such exercises. They answered questions from the CHNRI framework and their "collective optimism" towards each criterion was documented on a scale from 0 to $100 \%$.

Results: In the case of candidate vaccines for active immunization of infants against RSV, the experts expressed very low levels of optimism for low product cost, affordability and low cost of development; moderate levels of optimism regarding the criteria of answerability, likelihood of efficacy, deliverability, sustainability and acceptance to end users for the interventions; and high levels of optimism regarding impact on equity and acceptance to health workers. While considering the candidate vaccines targeting pregnant women, the panel expressed low levels of optimism for low product cost, affordability, answerability and low development cost; moderate levels of optimism for likelihood of efficacy, deliverability, sustainability and impact on equity; high levels of optimism regarding acceptance to end users and health workers. The group also evaluated immunoprophylaxis against RSV using monoclonal antibodies and expressed no optimism towards low product cost; very low levels of optimism regarding deliverability, affordability, sustainability, low implementation cost and impact on equity; moderate levels of optimism against the criteria of answerability, likelihood of efficacy, acceptance to end-users and health workers; and high levels of optimism regarding low development cost. They felt that either of these vaccines would have a high impact on reducing burden of childhood ALRI due to RSV and reduce the overall childhood ALRI burden by a maximum of about $10 \%$.
\end{abstract}

\footnotetext{
* Correspondence: Harry.Campbell@ed.ac.uk

† Contributed equally

${ }^{1}$ Centre for Population Health Sciences, Global Health Academy, The

University of Edinburgh, UK

Full list of author information is available at the end of the article
} 
Conclusion: Although monoclonal antibodies have proven to be effective in providing protection to high-risk infants, their introduction in resource poor settings might be limited by high cost associated with them. Candidate vaccines for active immunization of infants against RSV hold greatest promise. Introduction of a low cost vaccine against RSV would reduce the inequitable distribution of burden due to childhood ALRI and will most likely have a high impact on morbidity and mortality due to severe ALRI.

\section{Background}

Respiratory Syncytial Virus (RSV) is the commonest cause of acute lower respiratory tract infections (ALRI), here defined as pneumonia and bronchiolitis, in children under the age of 5 years (22\% of all ALRI episodes) and is estimated to be responsible for about 53,000 to 199,000 deaths annually [1]. A majority of the episodes of RSVassociated ALRI in young children occur in the first year of life. Stang estimated that the annual economic burden due to RSV-LRI hospitalisation in the United States alone is $\$ 43.2$ to $\$ 69.1$ million for all children aged less than 5 years and $\$ 36.5$ to $\$ 58.5$ million in the case of infants [2]. RSV is thought to account for approximately $85 \%$ of cases of bronchiolitis and approximately $20 \%$ of cases of childhood pneumonia [3]. Though in most cases the infection resolves without any sequelae, in some cases it can impact on the future health state of the child. Several studies have demonstrated an association between RSV infection in the first two years of life and the subsequent development of wheezing and LRI hospitalisations in the first decade of life [4-7]

Presently, there is no effective vaccine to combat this significant disease burden. Several candidate vaccines as well as immunoprophylaxis which hold promise are under various stages of development. We aimed to review the existing literature, outlining the progress of the emerging vaccines and immunoprophylaxis against RSV at all stages of development; present the evidence regarding key issues surrounding these products and assess the level of collective optimism of international experts over its priority status for receiving investment support. The paper is presented as part of a series of papers, each in turn focusing on different emerging vaccines and other interventions against pneumonia.

\section{Methods}

We used a modified Child Health and Nutrition Research Initiative (CHNRI) methodology for setting priorities in health research investments. The methodology has been described in great detail [8-12] and implemented in a variety of settings [13-18].

\section{CHNRI exercise - stage I: identification and selection of studies}

We conducted a systematic literature review using the following criteria: answerability, cost of development, cost of product, cost of implementation, efficacy and effectiveness, deliverability, affordability, sustainability, maximum potential impact on disease burden reduction, acceptability to health workers, acceptability to end users and equity [15] (Figure 1). The following search terms: respiratory syncytial virus, vaccination, immunization, infants, and children were used. Specific terms were used for active and maternal immunization and for the specific criteria using MeSH headings and truncation (Supplementary table S1 in additional file 1). The search was limited to Ovid MEDLINE, Embase, Global Health, Web of Science, LILACS, IndMed, and grey literature (SIGLE) databases from January 1994 to July 2009 (updated in August 2010). This was supplemented with hand searching of online journals and scanning of reference lists of identified citations. A total of 3138 articles were identified initially of which 70 articles were found suitable for full-text review. The inclusion and exclusion criteria are outlined in Table 1.

\section{CHNRI exercise - stage II: an expert opinion exercise}

We shared the initial review of the literature with 20 experts. The list of chosen experts included five leading basic scientists, five international public health researchers, five international policy makers and five representatives of the pharmaceutical companies. The 20 experts were chosen based on their excellent track record in child health research (but were not specifically involved with RSV disease research). We initially offered participation to the 20 experts with the greatest impact of publications in their area of expertise over the past 5 years (for basic researchers and international public health researchers), or for being affiliated to the largest pharmaceutical company in terms of vaccination programme or international agency in terms of their annual budget. For those who declined to participate (4 experts - about 20\% - mainly due to conflicting arrangements/ travel), replacements were found using the same criteria: for basic scientists and public health researchers we used Web of Knowledge and "ALRI" as search subject and limited time period to 2001-2008. This gave us a larger number of papers, which we sorted according to number of citations received. Then, we went down the ranks and invited the corresponding authors of the studies that were most relevant to the topic of our expert panel. The policy makers and industry representatives 


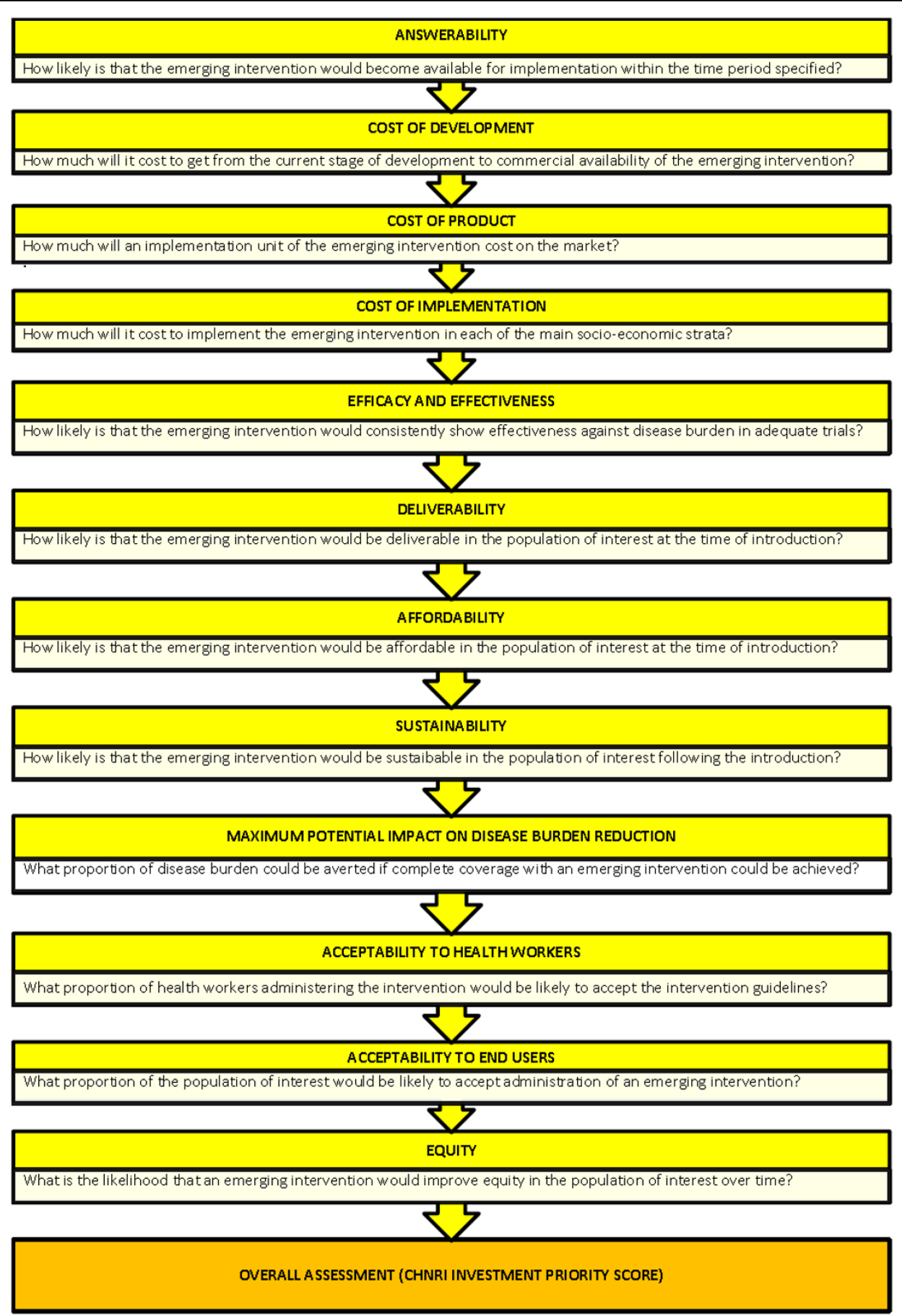

Figure 1 A summary of Stage I of the CHNRI process of evaluation of an emerging intervention (a systematic review of the key CHNRI criteria). CHNRI- Child Health and Nutrition Research Initiative.

accepted our invitation on the condition of anonymity, due to sensitive nature of their involvement in such exercises. About half of the experts were either affiliated to institutions in developing countries or had previous experience of working in developing country settings. The experts met during September 7-13, 2009 in
Dubrovnik, Croatia, to conduct the 2nd stage of CHNRI expert opinion exercise. The process of second-stage CHNRI is shown in Figure 2. All invited experts discussed the evidence provided in CHNRI stage I, and then answered questions from CHNRI framework (Supplementary table S2 in additional file 1). Their answers 
Table 1 Details of eligibility criteria used for screening the studies

\begin{tabular}{ll}
\hline Inclusion criteria & Exclusion Criteria \\
\hline - Included research into RSV & - RSV vaccine candidate was not a \\
vaccine, or other vaccine that & focus of the paper \\
may bear resemblance to future & \\
RSV vaccination programs & \\
- Vaccine research was targeted & - Bovine RSV vaccine or vaccine for \\
at children under 5 years & the elderly \\
- Gave an indication of & - Papers not directly relating to \\
$\begin{array}{l}\text { answerability, efficacy, } \\
\text { effectiveness, delivery, disease } \\
\text { burden reduction or impact on }\end{array}$ & impact \\
equity of a vaccine & \\
\hline
\end{tabular}

could have been "Yes" (1 point), "No" ( 0 points), "Neither Yes nor No" (0.5 points) or "Don't know" (blank). Their "collective optimism" towards each criterion was documented on a scale from 0 to $100 \%$. The interpretation of this metric for each criterion is straightforward: it is calculated as the number of points that each evaluated type of emerging RSV vaccine received from 20 experts (based on their responses to questions from CHNRI framework), divided by the maximum possible number of points (if all answers from all experts are "Yes") [8-12].

\section{Results}

We identified 70 articles and product monographs for inclusion. Currently several products are in development phase, most of which have completed phase I and II clinical trials (Figure 3 and Figure 4).

\section{Answerabilty - is the science behind the research viable?}

The first RSV vaccine (a formalin inactivated whole virus preparation) developed over 40 years ago was associated with increased disease severity in the vaccine recipients compared to RSV infected controls [19]. Since then although there have been numerous reports (especially over the past two decades) of an effective vaccine being "just round the corner", such a vaccine has been as elusive as ever.

\section{Active immunization}

The challenge currently facing live RSV vaccine developers is the appropriate balance between attenuation and immunogenicity [20]. This is a key challenge to overcome for RSV particularly as the virus primarily affects infants in the first 6 months of life [1]. The immune system at this age is immature and infants have a diminished B-cell response to infection which is an obstacle to achieving high titres of antibody [21]. Young infants also exhibit low $\mathrm{T}$ helper cells and inefficient antigen presentation. The poor response is accentuated by the effect of maternal antibodies, which have shown to suppress build-up of high serum neutralising antibody in response to immunization [22]. Live RSV vaccine shedding is not influenced by maternal antibody but is much greater in the naive child than in adults and older children with prior infection - a strong argument that there is substantial immunity to RSV. Thus there is only a narrow window between sufficient attenuation and effective immunogenicity.

Though there are shared epitopes, a potential vaccine may need to target two subtypes (A and B) further complicating the development process [23]. RSV has two proteins - F and G - which trigger the antibody response. Protein F and the central core of protein $\mathrm{G}$ remain constant in both strains and thus are major targets for subunit vaccines. G protein variability leads to the two antigenically distinguishable strains.

There is currently optimism regarding using reverse genetics technology to produce attenuated, genetically engineered live vaccines as a potential solution to several challenges faced in RSV vaccine development. The technique allows site directed mutations or gene deletions into the viral genome [24]. Several mutations can be introduced into the genome by this process to create a combination that achieves optimal levels of attenuation and immunogenicity. Current live vaccines under trial use gene deletion of protein NS2, which is known to prevent initiation of an innate immune response to viral infections [25]. Alternatively, chimeric vaccines can be created with a backbone of an attenuated virus other than RSV expressing immunogenic RSV proteins. This deletion has produced vaccines that appear to be sufficiently attenuated in infants and are thus a promising route [26].

Finding a suitable animal model for preclinical trials has been difficult due to host range restriction of RSV and the difficulty in mimicking the young age of the target population [21]. Most animal models are more resistant to the virus than young infants; thus the vaccine appears to be safer than it may be in the target population. The pace of development of novel vaccines is limited by the need for progressive clinical trials in adults and then in sero-positive children before it is deemed safe for trials in sero-negative infants. There is also a lack of a full understanding of the role played by the host immune system in the pathogenesis of natural RSV disease and in prediction of adverse reactions to vaccinations [21,27]. These challenges have prevented development of a vaccine for active immunization against RSV in infants below the age of 6 months. Nevertheless, there are currently several candidates at various stages of clinical trials and scientists are now hopeful of achieving in the near future a vaccine that is sufficiently attenuated and yet immunogenic and protective in young infants. The panel of experts expressed moderate levels of optimism (score around 60\%) concerning the 


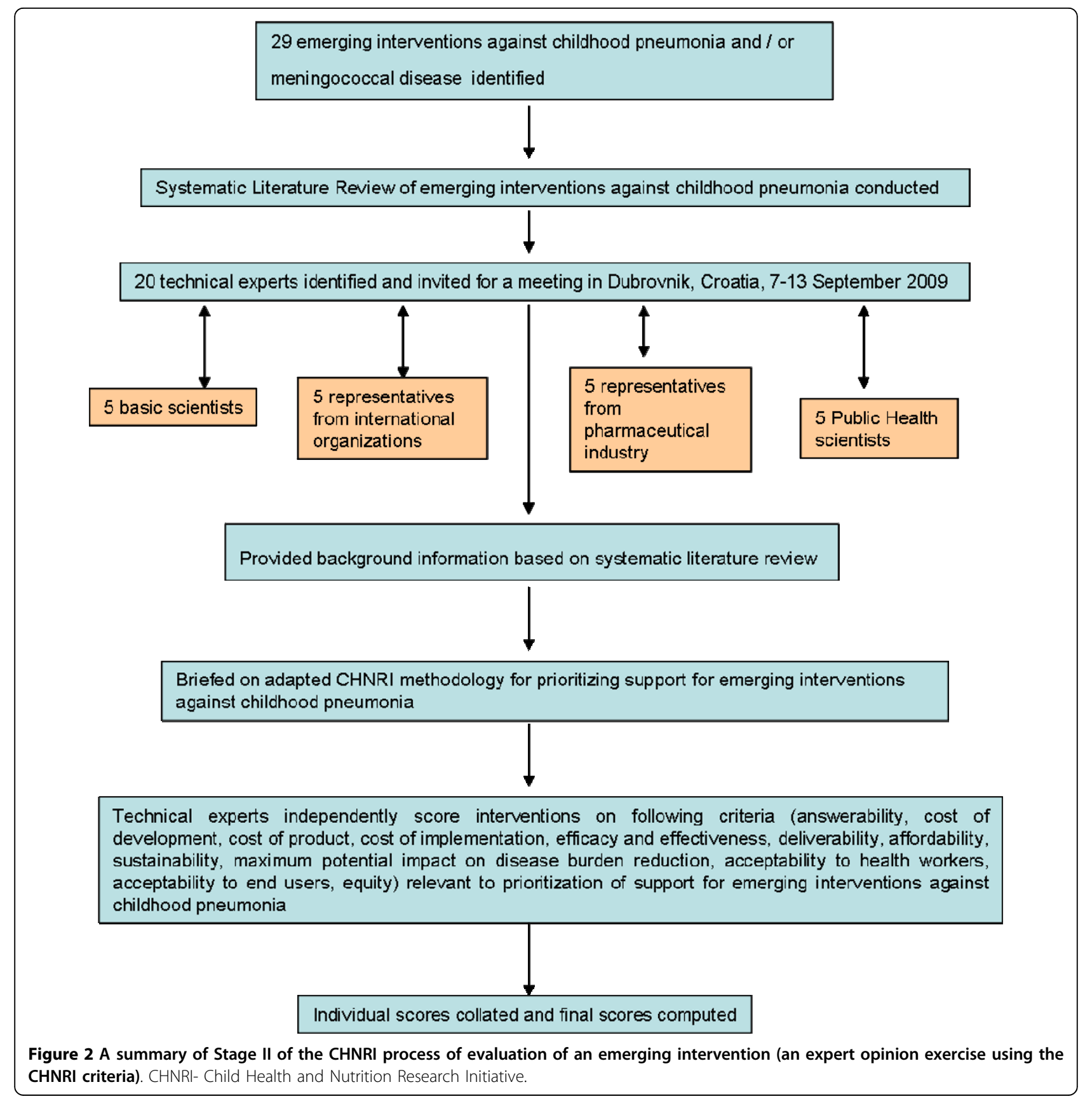

ability of vaccines for active immunization against RSV to satisfy the criterion of answerability (Figure 5).

\section{Maternal immunization}

Maternal immunization aims to vaccinate women during late pregnancy in order to provide increased passive immunity to infants by antibodies transferred from placenta and breast feeding. Antibodies are transferred from mother to foetus by active transport after 32 weeks gestation [28]. It has been shown that high levels of maternal antibody protect babies from severe RSV related disease and hospitalisation in the first year of life
$[29,30]$. This is particularly promising as a successful candidate maternal vaccine would protect infants aged less than 6 months who form the bulk of the disease burden and for whom it is proving to be difficult to develop active immunization. Only one candidate of a purified fusion protein (PFP) subunit vaccine has thus far entered clinical trials [31,32]. This approach is strengthened by the ability of higher titre monoclonal antibodies to protect infants when given prophylactically in the post-partum period. Glezen and colleagues have demonstrated that the protection against RSV infection 


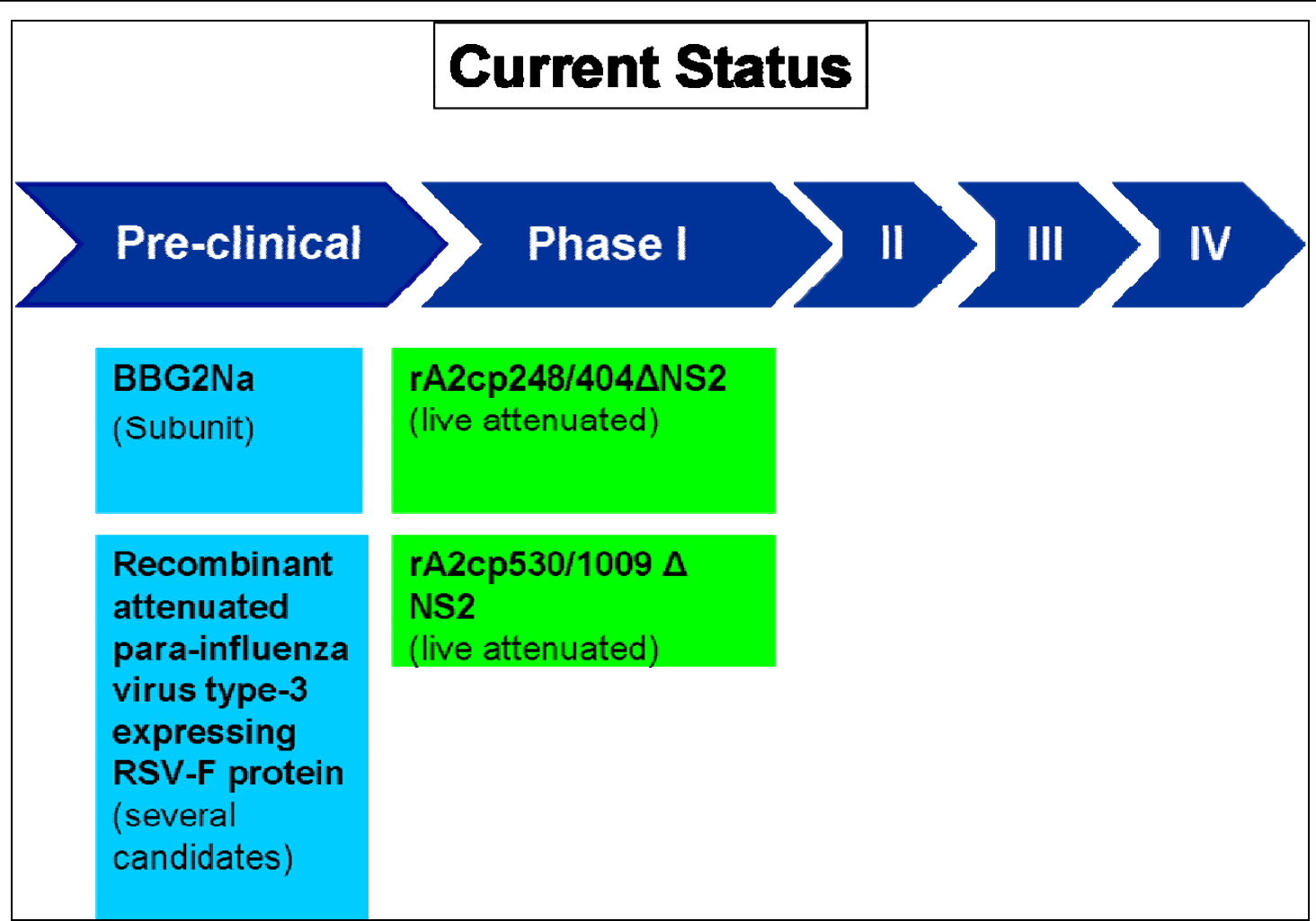

Figure 3 The current status of the research into RSV vaccines for active immunization. RSV- respiratory syncytial virus.

in early infancy is correlated with maternal antibody [33]. Active transport of maternal antibodies only occurs during the last trimester and may not be effective in case of premature babies (at particular risk of serious RSV related illness). Further trials using PFP subunit vaccines has since been discontinued since there are concerns about the safety of subunit RSV vaccines [34]. Presented with this evidence, the panel of experts expressed a low level of optimism (score around 40\%) concerning the ability of vaccines for maternal immunization against RSV to satisfy the criterion of answerability (Figure 6).

\section{Passive immunization}

Current vaccines for passive immunization against RSV deliver protection against active disease to infants at high risk during the peak RSV season. These

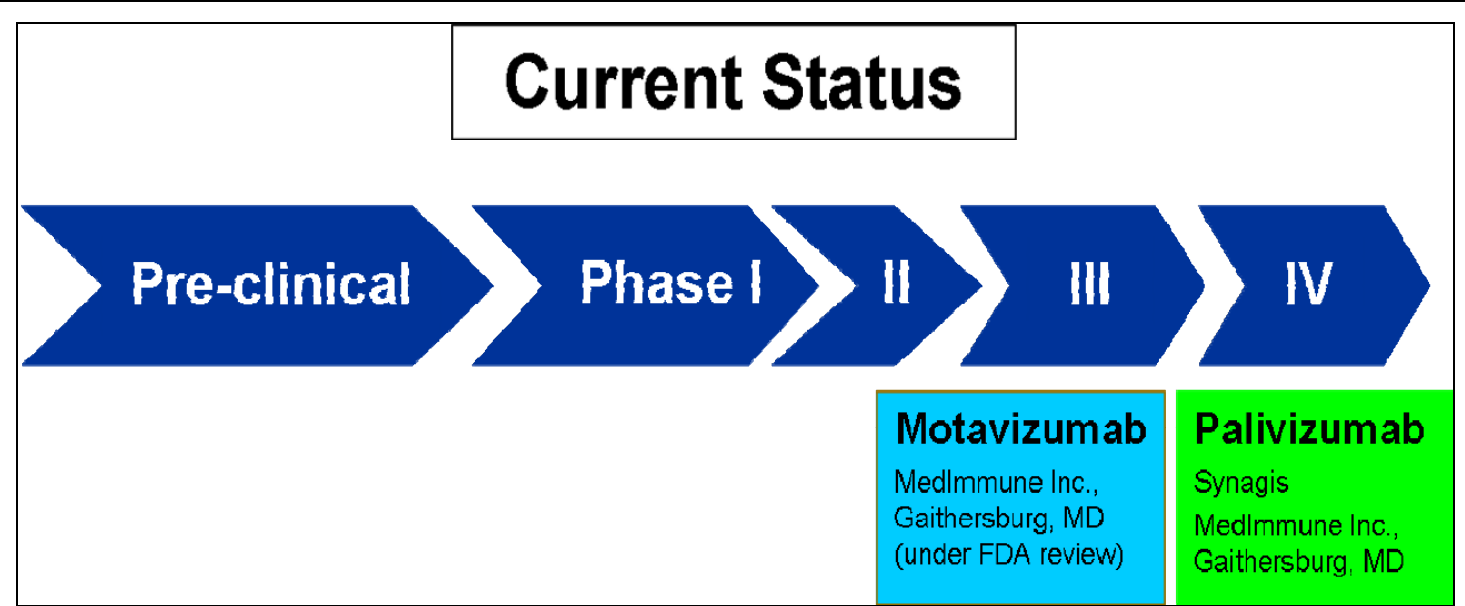

Figure 4 The current status of the research into immunotherapy against RSV. RSV- respiratory syncytial virus. 


\section{Anti-RSV vaccine for use in infants}

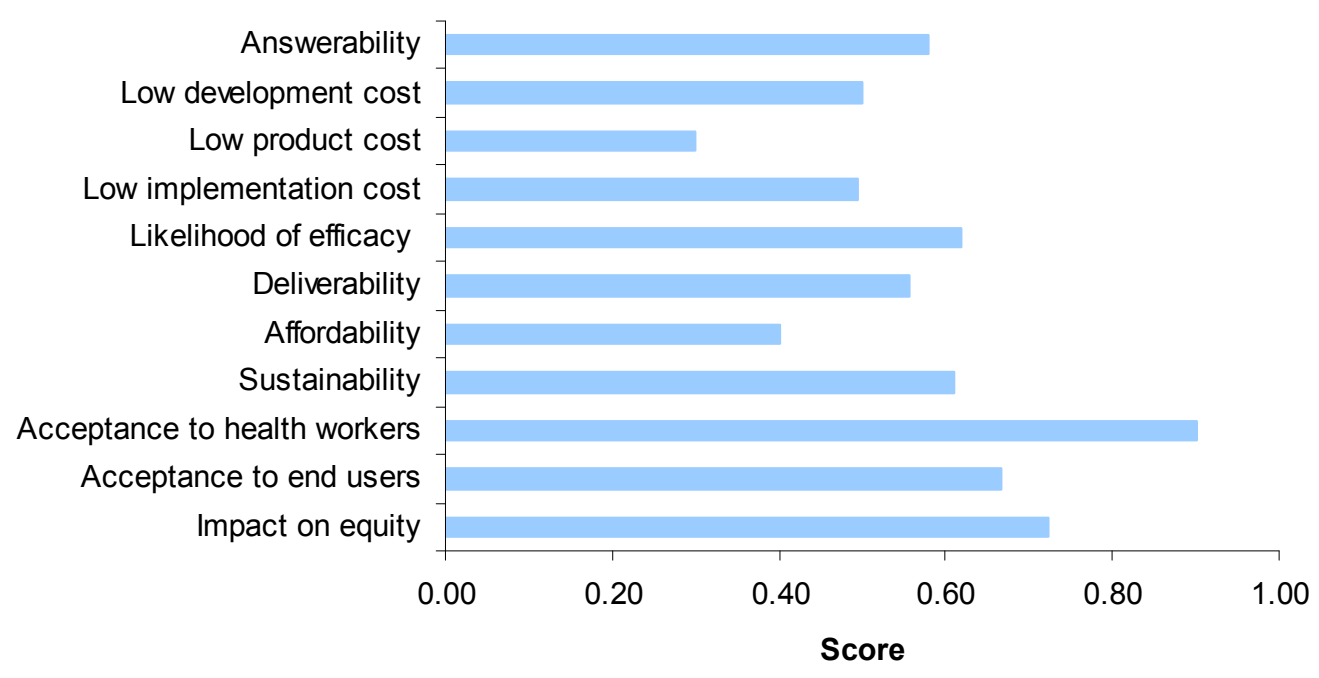

\section{Maximum Burden Reduction for infants anti-RSV vaccine} Box-and-Whisker plot of the experts' score

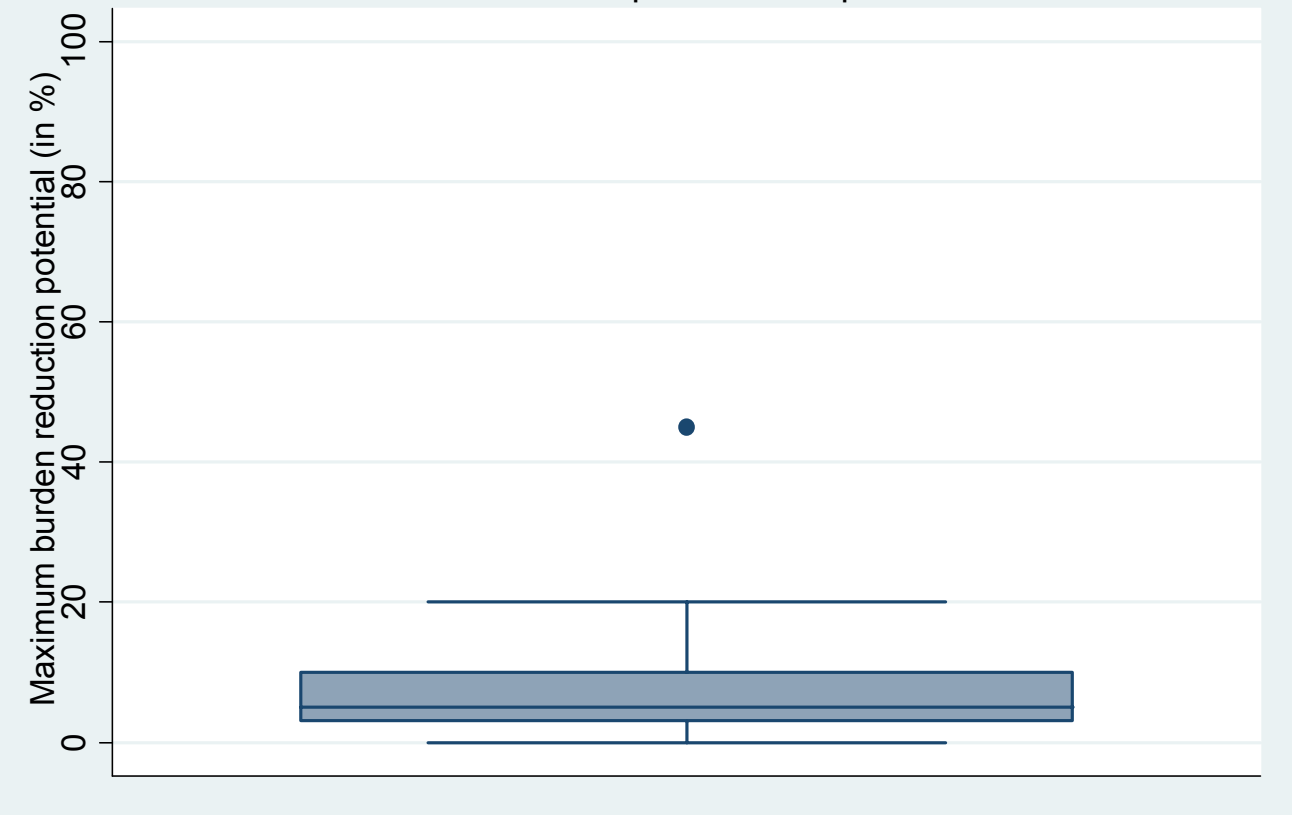

Figure 5 The results of Stage II of the CHNRI process - an expert opinion exercise assessing the potential usefulness of investment in vaccines for active immunization of infants against RSV. CHNRI- Child Health and Nutrition Research Initiative.

interventions raise serum neutralizing antibody. There have been two products in the market; RSV immune globulin (RespiGam; MedImmune Inc., Gaithersburg, MD) containing high-titre human polyclonal RSV antibodies [35] and Palivizumab (Synagis; MedImmune Inc.) a humanized murine monoclonal antibody against RSV
[36]. The more recent Palivizumab is now widely used as it has fewer adverse effects. In countries where Palivizumab is currently used; it is largely only approved for the prevention of severe RSV disease in premature infants, those with bronchopulmonary dysplasia or haemodynamically unstable chronic heart failure. A more 


\section{Anti-RSV vaccine for use in pregnant women}

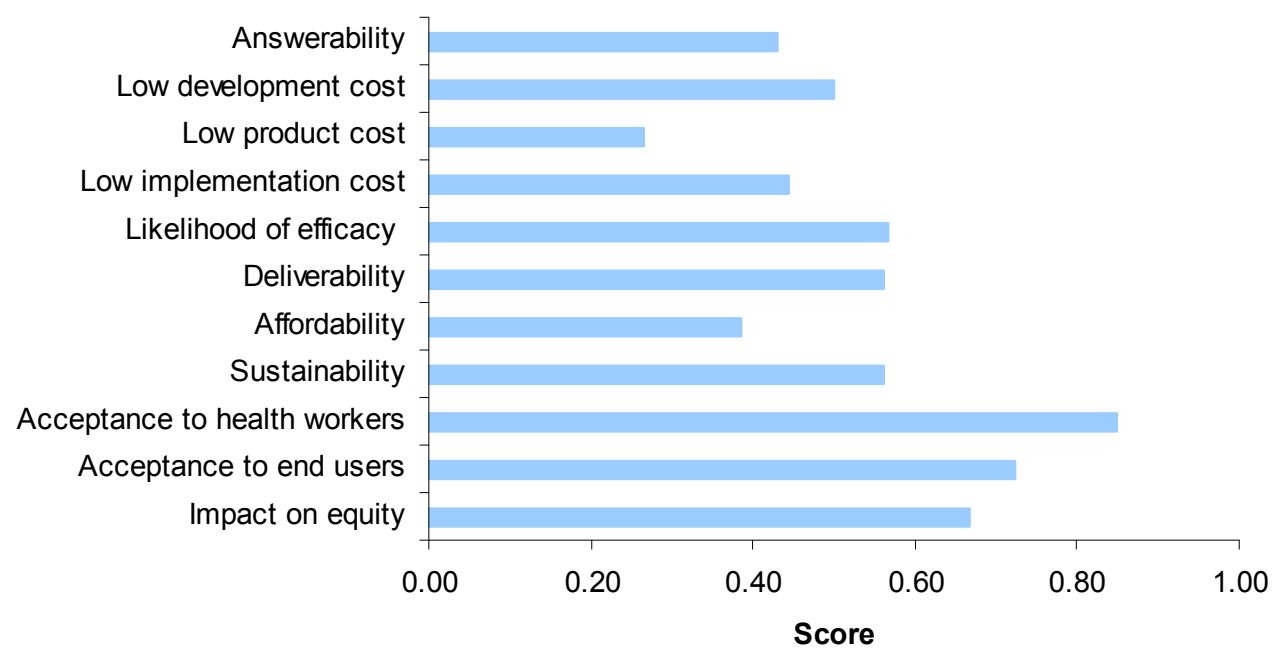

Maximum Burden Reduction for pregnant women anti-RSV vaccine

Box-and-Whisker plot of the experts' score

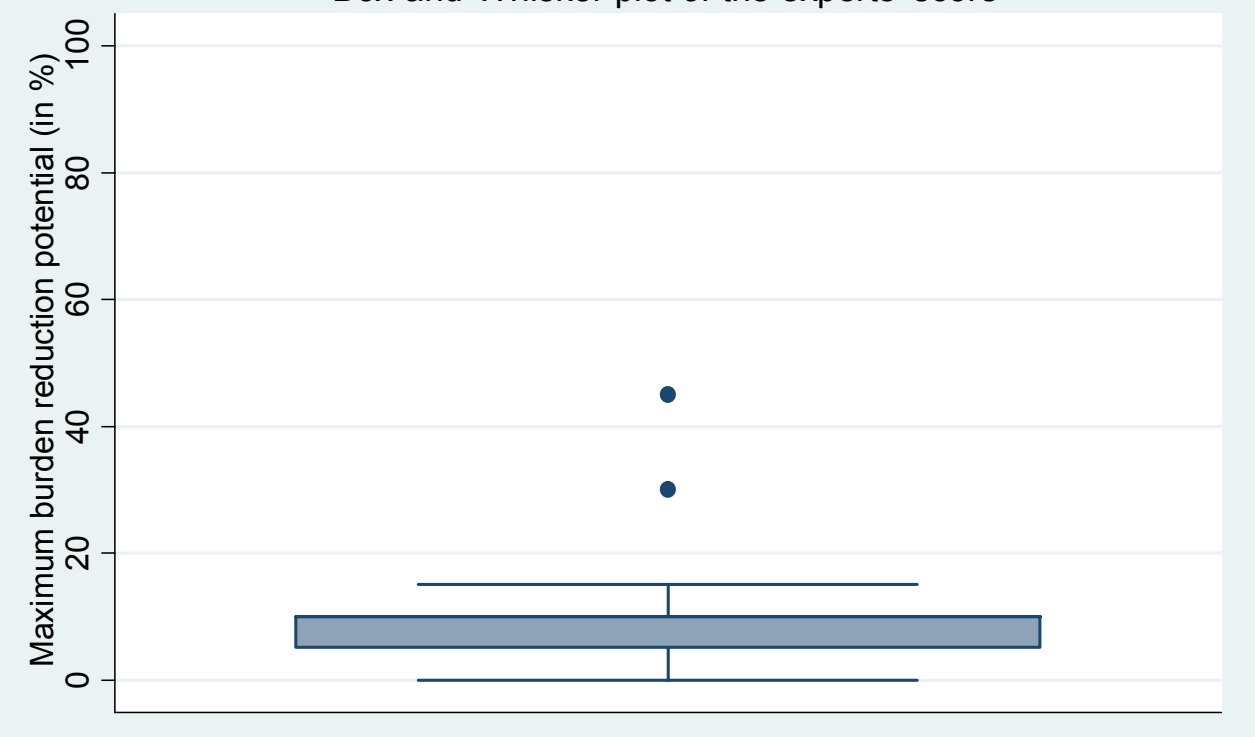

Figure 6 The results of Stage II CHNRI process - an expert opinion exercise assessing the potential usefulness of investment in vaccines for immunization of pregnant women with vaccines against RSV. CHNRI- Child Health and Nutrition Research Initiative.

potent derivative of Palivizumab - Motavizumab - has been evaluated and shows increasing efficacy against medically attended LRI but was non inferior for RSV hospitalization [37]. It is now awaiting US FDA approval [38]. Based on these evidence, the panel of experts expressed moderate to high levels of optimism (score around $70 \%$ ) regarding the ability of monoclonal antibodies to satisfy the criterion of answerability (Figure 7 ).
Efficacy - the impact of the vaccines under ideal conditions

Active immunization

The efficacy results of the various candidate vaccines for active immunization against RSV are summarized in Table 2. Immunization with RSV vaccine is unlikely to prevent RSV infection altogether [39]. Natural infection in an infant does not mount a robust enough immune 


\section{Monoclonal antibodies for passive immunization against \\ RSV}

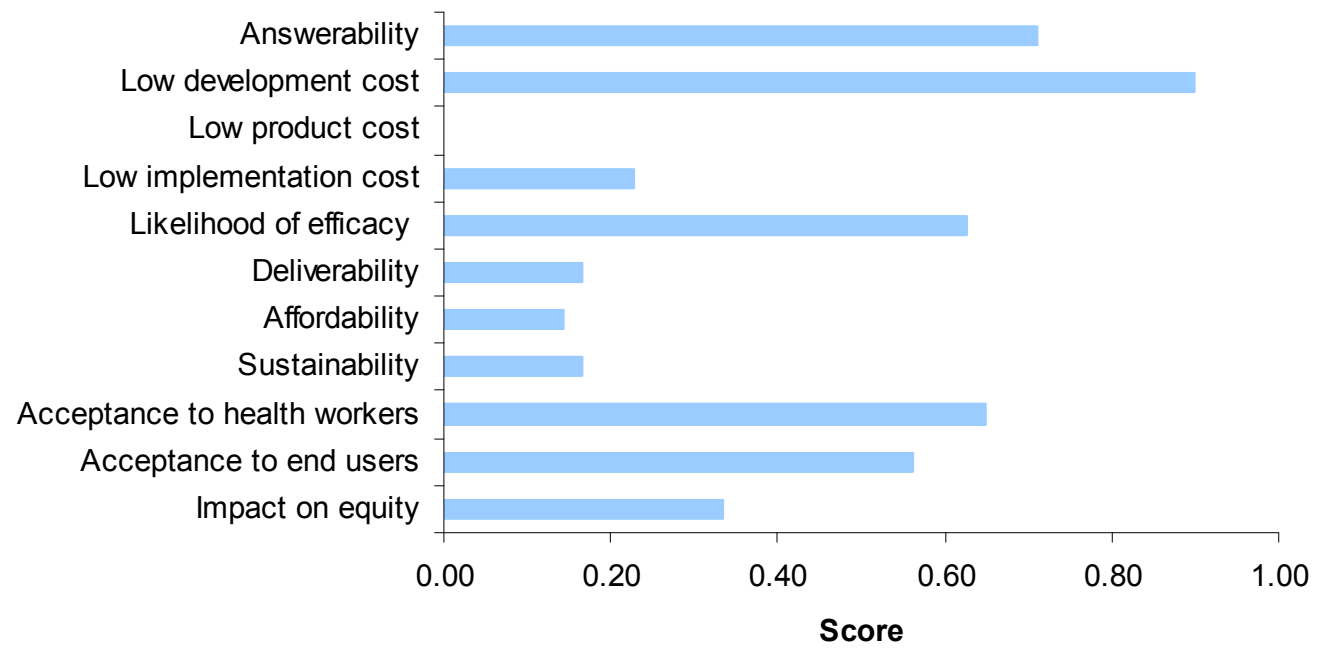

\section{Maximum Burden Reduction for monoclonal antibodies} for passive immunization against RSV

Box-and-Whisker plot of the experts' score

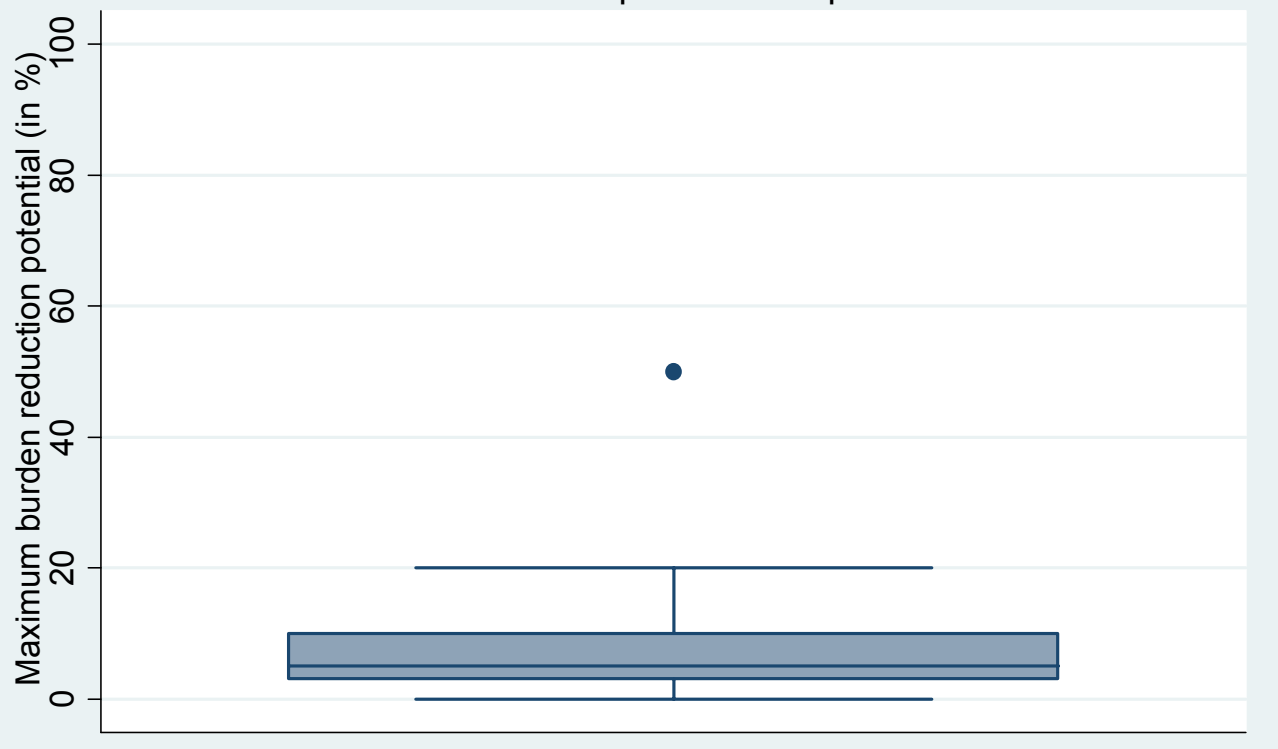

Figure 7 The results of Stage II CHNRI process - an expert opinion exercise assessing the potential usefulness of investment in monoclonal antibodies for passive immunization of infants against RSV. CHNRI- Child Health and Nutrition Research Initiative.

response to prevent subsequent infection. A study in Texas shows that $83 \%$ of those infected in the first year of life were again infected in the second and $46 \%$ in their third year, showing that risk of infection only reduces after the second infection and second year [40].
It is thus hypothesised that a new candidate is likely to need multiple doses at frequent intervals to achieve adequate immunity against RSV infection [41], making it difficult to have a successful immunization programme in low-income countries. Thus any vaccine against RSV 
Table 2 Efficacy results of candidate vaccines for active immunization against respiratory syncytial virus

\begin{tabular}{|c|c|c|c|}
\hline Class & Vaccine structure & Clinical trial phase & Results \\
\hline $\begin{array}{l}\text { Live } \\
\text { attenuated } \\
{[74]}\end{array}$ & 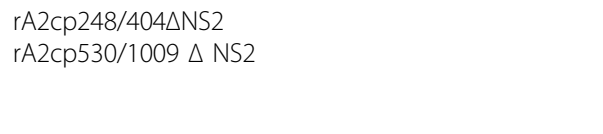 & 1 & $\begin{array}{l}\text { - Not infectious in adults } \\
\text { - Well tolerated, no symptomatic illness } \\
\text { - Infected } 50 \% \text { and } 20 \% \text { sero-negative infants } \\
\text { respectively at a dose of } 10^{5} \text { pfu }\end{array}$ \\
\hline $\begin{array}{l}\text { Live } \\
\text { attenuated } \\
{[24]}\end{array}$ & rA2cpts248/404/1030/ $\triangle \mathrm{SH}$ & 1 & $\begin{array}{l}\text { - only candidate with a demonstrated safety profile } \\
\text { - } 44 \% \text { vaccinated infants had detectable antibodies } \\
\text { after } 2 \text { doses of } 5.3 \log _{10} \text { pfu }\end{array}$ \\
\hline $\begin{array}{l}\text { b/hPIV3/ } \\
\text { RSVF2[44] }\end{array}$ & $\begin{array}{l}\text { Recombinant attenuated para-influenza virus type-3 } \\
\text { expressing RSV-F protein }\end{array}$ & I & $\begin{array}{l}\text { - tested in } 1201-9 \text { year old sero-positive children. } \\
\text { - acceptable safety profile } \\
\text { - minimally immunogenic }\end{array}$ \\
\hline $\begin{array}{l}\text { Subunit } \\
{[32,75,76]}\end{array}$ & Purified F Protein - PFP 1 and PFP 2 & $\begin{array}{l}\text { Discontinued after } \\
\text { phase I/ II }\end{array}$ & $\begin{array}{l}\text { - Pilot study shows significant antibody titres in } \\
\text { children with CF } \\
\text { - Safe and immunogenic in 12-48 month old sero- } \\
\text { positive children }\end{array}$ \\
\hline $\begin{array}{l}\text { Subunit } \\
{[75,76]}\end{array}$ & PFP 3 & $\begin{array}{l}\text { Discontinued after } \\
\text { phase II }\end{array}$ & $\begin{array}{l}\text { - Double blinded controlled multi-centre study in CF } \\
\text { children } \\
\text { - Safe and immunogenic but no reduction in LRTI }\end{array}$ \\
\hline $\begin{array}{l}\text { Subunit } \\
{[75,76]}\end{array}$ & $\mathrm{BBG} 2 \mathrm{Na}$ & Animal models & $\begin{array}{l}\text { - Safe and immunogenic in adult mice. } \\
\text { - Phase III trials in adult volunteers stopped due to } \\
\text { unexpected adverse effects }\end{array}$ \\
\hline
\end{tabular}

which would eventually be licensed may only be able to provide protection against severe ALRI, hospitalisation and death which account for the greatest disease burden. It is also likely that these vaccines could prevent sequelae and bacterial super-infection as a result of RSV infection.

All of the live vaccines are being designed for intranasal delivery using the model of the cold-adapted influenza vaccine, Flumist ${ }^{\circledR}$. It is hoped that this will increase its efficacy by enhancing mucosal immunity as this is believed to play an important role in RSV infection. Despite several trials of subunit vaccines, none have been conducted on young sero-negative children. Such trials are unlikely to be seen in the near future mainly because of our incomplete understanding of the events leading to the enhanced disease seen with the Formalininactivated vaccine [34] and the fact that development of PFP, (the most promising candidate), and other subunit vaccines have been discontinued due to almost uniformly low immunogenecity.

A recombinant attenuated para-influenza type-3 candidate incorporating RSV protein $\mathrm{F}$ has also been created using reverse genetics technology and aims to protect against both viruses $[42,43]$. A candidate vaccine was recently shown to be safe in seropositive children though with inadequate immunogenicity [44]. There are a host of other candidates using other viruses as vectors such as adenovirus, Sendai virus, Newcastle disease virus, vaccinia virus and Venezuelan equine encephalitis virus which are beyond the scope of this paper [45-53]. Presented with these evidence, the panel of experts expressed moderate levels of optimism (score around 60\%) regarding the ability of vaccines for active immunization against RSV to satisfy this criterion (Figure 5).

\section{Maternal immunization}

The subunit vaccine using Purified Fusion Protein-2 was not immunogenic enough in mothers and only low antibody titres were achieved thus necessitating the need for a more potent candidate vaccine [31]. Furthermore, research into PFP candidates has since been discontinued. The panel of experts however expressed moderate levels of optimism (score around 60 percent) regarding efficacy of the vaccine in case one such were to be developed (Figure 6).

Passive immunization

Passive immunization against RSV with monoclonal antibodies is highly efficacious. The results of the recent trials using monoclonal antibodies are summarized in Table 3. Here too the experts expressed moderate levels of optimism (score around 60\%) regarding efficacy of this intervention (Figure 7).

\section{Effectiveness- maximum burden reduction potential}

Nair and colleagues estimated that in the year 2005, 33.8 million new episodes of RSV-associated ALRI occurred globally in children aged less than 5 years, of which 3.4 million were severe enough to result in hospitalisation [1]. Ninety six percent of these episodes were in developing countries. They also estimated that in the year 2005 , roughly 53,000 to 199,000 children younger than 5 years of age died from RSV associated ALRI, with 99\% of these deaths occurring in developing countries.

Developing an effective vaccine for active immunization against RSV would result in a significant reduction of disease burden from RSV infections. However, at 
Table 3 Efficacy results of candidate vaccines for passive immunization against respiratory syncytial virus

\begin{tabular}{|c|c|c|c|}
\hline Class & $\begin{array}{l}\text { Vaccine } \\
\text { structure }\end{array}$ & $\begin{array}{l}\text { Clinical trial } \\
\text { phase }\end{array}$ & Results \\
\hline Human polyclonal $[77,78]$ & RSV IVIG & $\begin{array}{l}\text { Passed clinical } \\
\text { trials }\end{array}$ & $\begin{array}{l}\text { - } 40.7 \% \text { relative reduction in hospitalization compared to placebo } \\
\text { - } 63.4 \% \text { relative reduction in hospitalization compared to placebo }\end{array}$ \\
\hline $\begin{array}{l}\text { Humanized monoclonal lg } \\
\text { [36] }\end{array}$ & Palivizumab & $\begin{array}{l}\text { Passed clinical } \\
\text { trials }\end{array}$ & - $54.7 \%$ relative reduction in hospitalisation compared to placebo \\
\hline $\begin{array}{l}\text { Humanized monoclonal lg } \\
\text { [37] }\end{array}$ & Motavizumab & III & $\begin{array}{l}\text { - } 50 \% \text { relative reduction in medically attended LRI compared to } \\
\text { Palivizumab. } \\
-26 \% \text { relative reduction in hospitalisation compared to Palivizumab. }\end{array}$ \\
\hline
\end{tabular}

present it is not possible to precisely quantify of the maximum reduction of disease burden using the RSV vaccines without any information on the vaccine effectiveness. None of the vaccine candidates have passed phase III trials. The potential for a RSV vaccine for herd immunity also remains to be seen.

Though effectiveness of maternal immunization against RSV in the general population cannot be elicited at this stage, there are potential barriers to attaining a high degree of effectiveness in low-income countries. High levels of malaria in pregnant women are worrying as this has been shown to impede active placental transport in the case of maternal immunization against tetanus. In The Gambia, there was a $58 \%$ reduction in the transfer of trans-placental antibody against RSV in association with placental malaria [54].

Several trials have been carried out to assess effectiveness of Palivizumab across high-income countries such as USA, Canada, France and Netherlands [55]. A study in the USA including 2095 children showed hospitalization rates of $2.9 \%$ in infants on Palivizumab. In a Canadian study with 480 infants hospitalisation rates were half of that quoted in the Impact-RSV study [36]. Though these studies have consistently reinforced the safety and high effectiveness of Palivizumab, none of these have been conducted in low and middle-income countries. The panel was of the opinion that candidates for all three interventions are likely to have low levels of maximum impact on overall pneumonia disease burden (Figures 5, 6 and 7).

\section{Cost of development, product and implementation and affordability}

In the case of candidate vaccines for active immunization of infants against RSV, and also the candidate vaccines targeting pregnant women, the experts expressed very low levels of optimism for low product cost, affordability and low cost of development. The group also evaluated immunoprophylaxis against RSV using monoclonal antibodies and expressed no optimism at all towards low product cost; very low levels of optimism regarding affordability and low implementation cost, but high levels of optimism regarding low development cost
(Figures 5,6,7). Clearly, cost of the product and its implementation in developing country settings has been the major concern of the expert panel related to all emerging interventions against RSV.

\section{Deliverability, sustainability and acceptability Active immunization}

Live attenuated vaccines - currently the most promising candidates - are being developed with intranasal delivery. Along with a likely increase in effectiveness, this would also make delivery easier due to minimal training needs and a potential saving in total cost due to this. Such a delivery method would obviate transmission of blood borne infections such as Hepatitis B and HIV associated with poor needle handling in low-income countries. With candidates being at very early stages of trials, there is little indication of where-if at all-it may fit into the expanded programme on immunization (EPI) schedule [56]. However, a potential limitation of a likely candidate is the need for multiple doses. This may reduce uptake depending on the number of doses and the time interval between each, as it may not complement the current EPI schedule. Additionally, there are no data on interactions of candidate vaccines with others in the EPI schedule [57]. It is also hugely concerning that unlike Flumist ${ }^{\circledR}$, all live attenuated candidates thus far have required storage facilities below $-70^{\circ}$ $\mathrm{C}$ which would not fit with current cold chains in most countries and is not at all feasible in low-income countries [23]. It is hoped that this obstacle would be overcome as the vaccine progresses through further clinical trial stages. Finally, the safety of live RSV vaccines, in relationship to development of recurrent wheezing and asthma later on is a theoretical concern but needs to be studied before it is widely used. The panel expressed moderate levels of optimism (score around 60 percent) on the criteria of deliverability, sustainability and acceptability to end users of these vaccines for active immunization against RSV (Figure 5). However, they expressed high level of optimism (score over $80 \%$ ) on the acceptability of these vaccines to the health workers.

As candidate vaccines have not yet reached phase IV clinical trials, there are no cost estimates for these new 
interventions. However, being a new vaccine, initial prices are likely to be high especially with a high demand for the vaccine in high-income countries. A way of making an emerging intervention more deliverable in low and middle-income countries could be with differential pricing of the product [58]. This works by licensing a vaccine with the agreement of setting lower and more affordable prices in low and middle-income countries. The model has potential to work well in the case of RSV as there is a great demand for a RSV vaccine in the developed countries, which would thus be able to heavily subsidise the cost in the developing countries. Since majority of the disease burden due to RSV and influenza occur in very young children (in the first two years of life), and both diseases have strong seasonal pattern of transmission and the lower respiratory infection associated with both are known to progress rapidly, extrapolation of cost effectiveness using analyses for an influenza vaccine may be useful. Salo and colleagues demonstrated that investing 1.1 million Euros on vaccinating children with an influenza vaccine between 6 months and 3 years, reduced medical costs by 2.8 million Euros, thereby resulting in a cost-saving 1.7 million Euros [59]. This is particularly promising as incidence rates were underestimated and showed potential savings with a vaccine efficacy as low as $60 \%$. Since the burden of disease with RSV is higher than that from influenza one could expect greater savings [60]. Additionally, benefits of potential herd immunity must be considered. However, this particular analysis was carried out in Finland and thus cannot be generalised globally. The experts however, expressed low levels of optimism (score less than 60 percent) regarding the ability to develop the vaccine at a low cost (Figure 5).

\section{Maternal immunization}

Health care utilization indicators suggest that an effective delivery system is in place for maternal immunization in many middle and low-income countries. Even in countries with low hospital delivery levels, a majority of women still attend antenatal care at least once. Greenwood points out that more than $50 \%$ of women in 24 of 28 African countries surveyed were found to attend antenatal clinics on four or more occasions [61]. In addition, in many malaria endemic countries, greater attendance is being encouraged through prevention programs in order to deliver prophylactic treatment. The high coverage achieved by maternal immunization programs against tetanus is also particularly encouraging as neonatal tetanus is a particular problem of extremely poor communities [62]. However, since vaccines for maternal immunization are still in early stages of development, there is as yet no indication of storage requirements for these vaccines. The experts expressed moderate levels of optimism (score around 60 percent) on the criteria of deliverability and sustainability of these vaccines (Figure 6). They however were more optimistic (score around 80 percent) on the acceptability of these vaccines to the end users and health workers. The panel expressed concern (score around 50 percent) about the ability to develop these vaccines at a low cost.

\section{Passive immunization}

Delivery of Palivizumab requires monthly injections for five months through the RSV season; this may prove difficult in low-income countries for several reasons. In the tropical and sub-tropical regions the seasonality of RSV is not very clear as in temperate regions $[63,64]$. Unlike in the US, the administration of Palivizumab in developing countries would most likely rely on the availability of hospital services which would make delivery difficult in resource poor settings which constitute the bulk of the disease burden. Administration of Palivizumab is only recommended in high-risk patients. Since this decision is based on clinical judgement, it is likely to be a limiting factor in low and middle-income countries where there is shortfall in health manpower. Palivizumab needs to be stored at 2 to $8^{\circ} \mathrm{C}$ which makes it suitable for utilizing existing cold chain facilities available under EPI [65]. Immunoprophylaxis with Palivizumab has primarily been in developed countries due to the high cost associated with it. Most economic analyses show that Palivizumab use is not cost-effective though some studies show greater cost-efficacy specifically for use in premature infants [66]. Economic analyses for the use of Palivizumab in Argentina demonstrated a cost of $\$ 15358$ per avoided hospitalization while the same was at a cost of $\$ 34840$ in an Aborigine community $[67,68]$. Studies in Malaysia show that a significantly better outcome was achieved for patients with RSV bronchiolitis in hospitals where better intensive care expertise and resource was available [69]. Many critics have argued that in countries where health resources are scarce, money may be better channelled into improving intensive care units than investing in an expensive new intervention. Since monoclonal antibodies have already been developed, the experts were highly optimistic (score around 90 percent) that they could be made available to low and middle income countries at a low cost (Figure 7). However, they were not optimistic (score around 20 percent) regarding the deliverability and sustainability of these interventions. They were however moderately optimistic (score around 60 percent) regarding the acceptability of these products to the end users and health workers.

\section{Impact on equity}

Though RSV affects young children across the world, 96 percent of the episodes occur in developing countries [1]. Thus an equitable coverage program needs to reach a vast proportion of the global poor. Evaluation of current immunization and treatment programs show that 
uptake of a new initiative is faster and more efficient in rich populations between and within countries. This is called inverse equity as the global poor are exposed to higher degrees of disease, yet effective interventions fail to reach them [70]. In many countries where several interventions are being promoted simultaneously (instead of encouraging universal coverage), these provide cumulative benefit to the rich and increase health inequalities. An evaluation of coverage of several interventions in 54 priority countries showed an average coverage of over $50 \%$ with less than $30 \%$ coverage in the poorest communities [71].

This disparity is less apparent in immunization programs than with some other interventions. Yet, in 50 low and middle-income countries average coverage for full immunization was $62 \%$ in the richest $20 \%$ and a mere $38 \%$ in the poorest $20 \%$ [72]. These evaluations highlight a large and growing equity gap which is precipitated by the addition of new interventions. While these interventions may be effective and succeed in reducing disease burden, a greater proportion of deaths could be prevented by aiming for universal coverage with fewer interventions. Thus a new RSV vaccine is only likely to be equitable if a novel delivery system that aims to target poor populations is adopted [73]. The panel was moderately optimistic (score around 70 percent) about the ability of the vaccines for active and maternal immunization to have an impact on equity (Figures 5, 6, and 7). However, they were not optimistic (score around 40 percent) about the ability of monoclonal antibodies to satisfy this criterion.

\section{Discussion}

RSV is the most common cause of ALRI in children and an important cause of child mortality with a high disease burden in low and middle-income countries. The literature review summarized in this paper presents evidence required for making an informed decision on the research priority that should be given to emerging interventions against RSV. The scores for active and passive immunization of infants and pregnant women with interventions against the set criteria represent the collective optimism of a panel of experts drawn from varying technical backgrounds and affiliations. Although there are currently no vaccines to protect against the virus, significant progress is being made for active immunization, with live attenuated preparations looking most promising. Recent research has increased hope for a successful vaccine for infants as young as 2 months. However, there have been no trials in low and middle-income countries which are essential to assess their impact in these areas where disease burden is highest. Pharmaceutical companies would need to seriously consider undertaking future clinical trials in developing countries without which no progress in reducing global childhood mortality associated with RSV can be anticipated.

In the case of candidate vaccines for active immunization of infants against RSV, the experts expressed low levels of optimism for cost of product, affordability and low cost of development and implementation; moderate levels of optimism regarding the criteria of answerability, likelihood of efficacy, deliverability, sustainability and acceptance to end users for the interventions; and high levels of optimism regarding impact on equity and acceptance to health workers. While considering the candidate vaccines targeting pregnant women, the panel expressed low levels of optimism for cost of product, affordability, low cost of development and implementation, and even answerability; moderate levels of optimism for likelihood of efficacy, deliverability, sustainability and impact on equity; high levels of optimism regarding acceptance to end users and health workers. The group also evaluated immunoprophylaxis against RSV using monoclonal antibodies and expressed no optimism at all towards low product cost; low levels of optimism regarding deliverability, affordability, sustainability, cost of implementation and the impact on equity; moderate levels of optimism against the criteria of answerability, likelihood of efficacy, acceptance to end-users and health workers; and high levels of optimism regarding low development cost. As far as the vaccines against RSV are concerned the challenge would be to develop a low cost, immunogenic yet safe vaccine which can be either given to infants younger than two months of age or develop one which can be given to pregnant women in their last trimester.

This is the first time such an exercise has been conducted with the aim of predicting the future impact of emerging vaccines. The CHNRI methodology was primarily designed to evaluate existing interventions and competing investment priorities for health research. Although we used the CHNRI criteria, we modified it by including systematic review of available literature and not involving all stakeholders (e.g. end-users and health workers). The scores reported in this paper express the collective opinion of a panel of 20 experts. While there is always an element of error while predicting impact of interventions which do not exist and have no clinical trial data to support them (especially efficacy and maximum disease burden reduction potential), we feel that the results would be reproducible with another panel in a different setting.

\section{Conclusions}

To summarize, while it is not only important that investments are made in researching new vaccines, adequate emphasis must be made and resources allocated for proper distribution of the vaccine. While 
vaccines for active immunization of infants appear to be the most promising, the search for a candidate vaccine which is immunogenic yet sufficiently attenuated is not yet over. It looks unlikely that maternal immunization would provide sufficient protection to young infants. And while monoclonal antibodies have proven to be effective in providing protection to high-risk infants, high costs and need for hospitalisation for delivery severely limit their generalisability. As more and more countries introduce vaccines against Streptococcus pneumoniae and Haemophilus influenzae type $B$ in their EPI, and coverage of these vaccines increases, the burden of disease due to bacterial pneumonias will inevitably decrease, thus further increasing the relative importance of viral causes. Moreover, as most bacterial pneumonias are secondary to viral ALRI, introduction of an effective vaccine against RSV will have a compounded effect on the overall morbidity and mortality due to childhood pneumonia.

\section{Additional material}

\section{Additional file 1: Supplementary tables 1 and 2.}

\begin{abstract}
Acknowledgements
This work was supported by the grant from the Bill and Melinda Gates Foundation No. 51285 ("Modelling the impact of emerging interventions against pneumonia").

This article has been published as part of BMC Public Health Volume 11 Supplement 3, 2011: Technical inputs, enhancements and applications of the Lives Saved Tool (LiST). The full contents of the supplement are available online at http://www.biomedcentral.com/1471-2458/11?issue=S3.
\end{abstract}

\section{Author details \\ ${ }^{1}$ Centre for Population Health Sciences, Global Health Academy, The University of Edinburgh, UK. ${ }^{2}$ Public Health Foundation of India, New Delhi, India. ${ }^{3}$ International Centre for Diarrhoeal Disease Research, Bangladesh (ICDDR,B), Dhaka, Bangladesh. ${ }^{4}$ University of Colorado Denver and The Children's Hospital, Denver, CO, USA. ${ }^{5}$ Division of Infectious Disease and International Health, Dartmouth Medical School, Lebanon, NH, USA. ${ }^{6}$ Croatian Centre for Global Health, University of Split Medical School, Croatia.}

\section{Authors' contributions}

HN participated in the design of the study, literature review, data collection, data analysis, data interpretation and prepared the initial draft of the manuscript. VRV participated in the design of the study, led the literature review, contributed to data collection and preparation of the initial draft of the manuscript. ET participated in design of the study, data collection, statistical analysis, data interpretation and critically reviewed the manuscript. LZ participated in the design of the study, data collection, data collection and critically reviewed the manuscript. TH, EAFS and PW contributed to data interpretation and critical review of the manuscript. IR and HC conceived of the study, participated in literature review, data collection, data interpretation, and critically reviewed drafts of the manuscript. All authors read and approved the final manuscript.

\section{Competing interests}

EAFS has in the past received consultancy, grants, and honoraria for lectures from Medlmmune and grants from Roche; however, no grants or honoraria were received for work included in this study. PFW has in the past received grant funding and honoraria from Sanofi-Aventis, Wyeth, Medlmmune and Merck; however, no grants or honoraria were received for work included in this study. HN, VRV, ET, LZ, TH, IR and HC declare that they have no competing interests.

Published: 13 April 2011

\section{References}

1. Nair H, Nokes D, Gessner B, Dherani M, Madhi S, Singleton R, O'Brien K, Roca A, Wright P, Bruce N, Chandran A, Theodoratou E, Sutanto A, Sedyaningsih E, Ngama M, Munywoki P, Kartasasmita C, Simoes E, Rudan I, Weber M, Campbell H: Global burden of acute lower respiratory infections due to respiratory syncytial virus in young children: a systematic review and meta-analysis. Lancet 2010, 375(9725):1545-1555.

2. Stang PE: The Economic Burden of Respiratory Syncytial VirusAssociated Bronchiolitis Hospitalizations. Arch Pediatr Adolesc Med 2001, 155(1):95-96.

3. Wright PF, Cutts FT: Generic protocol to examine the incidence of lower respiratory infection due to respiratory syncytial virus in children less than 5 years of age. Geneva: World Health Organization; 2000, 34.

4. Simoes EA, Carbonell-Estrany X, Rieger $\mathrm{CH}$, Mitchell I, Fredrick L, Groothuis JR: The effect of respiratory syncytial virus on subsequent recurrent wheezing in atopic and nonatopic children. J Allergy Clin Immunol 2010, 126(2):256-262.

5. Singleton RJ, Redding GJ, Lewis TC, Martinez P, Bulkow L, Morray B, Peters H, Gove J, Jones C, Stamey D, Talkington DF, DeMain J, Bernert JT, Butler JC: Sequelae of Severe Respiratory Syncytial Virus Infection in Infancy and Early Childhood Among Alaska Native Children. Pediatrics 2003, 112:285-290.

6. Sigurs N, Gustafsson PM, Bjarnason R, Lundberg F, Schmidt S, Sigurbergsson F, Kjellman B: Severe Respiratory Syncytial Virus Bronchiolitis in Infancy and Asthma and Allergy at Age 13. Am J Respir Crit Care Med 2005, 171:137-141.

7. Stein RT, Sherrill D, Morgan WJ, Holberg CJ, Halonen M, Taussig LM, Wright AL, Martinez FD: Respiratory syncytial virus in early life and risk of wheeze and allergy by age 13 years. Lancet 1999, 354(9178):541-545.

8. Rudan I, Gibson JL, Ameratunga S, El Arifeen S, Bhutta ZA, Black M, Black RE, Brown KH, Campbell H, Carneiro I, Chan KY, Chandramohan D, Chopra M, Cousens S, Darmstadt GL, Meeks Gardner J, Hess SY, Hyder AA, Kapiriri L, Kosek M, Lanata CF, Lansang MA, Lawn J, Tomlinson M, Tsai AC, Webster J: Setting priorities in global child health research investments: guidelines for implementation of CHNRI method. Croat Med J 2008, 49(6):720-733.

9. Rudan I: The complex challenge of setting priorities in health research investments. Indian J Med Res 2009, 129(4):351-353.

10. Rudan I, Chopra M, Kapiriri L, Gibson J, Ann Lansang M, Carneiro I, Ameratunga S, Tsai AC, Chan KY, Tomlinson M, Hess SY, Campbell H, El Arifeen S, Black RE: Setting priorities in global child health research investments: universal challenges and conceptual framework. Croat Med J 2008, 49(3):307-317.

11. Rudan I, El Arifeen S, Black RE, Campbell H: Childhood pneumonia and diarrhoea: setting our priorities right. Lancet Infect Dis 2007, 7(1):56-61.

12. Rudan I, Gibson J, Kapiriri L, Lansang MA, Hyder AA, Lawn J, Darmstadt GL, Cousens S, Bhutta ZA, Brown KH, Hess SY, Black M, Gardner JM, Webster J, Carneiro I, Chandramohan D, Kosek M, Lanata CF, Tomlinson M, Chopra M, Ameratunga S, Campbell H, El Arifeen S, Black RE: Setting priorities in global child health research investments: assessment of principles and practice. Croat Med J 2007, 48(5):595-604.

13. Bahl R, Martines J, Ali N, Bhan MK, Carlo W, Chan KY, Darmstadt GL, Hamer DH, Lawn JE, McMillan DD, Mohan P, Paul V, Tsai AC, Victora CG, Weber MW, Zaidi AK, Rudan I: Research priorities to reduce global mortality from newborn infections by 2015. Pediatr Infect Dis J 2009, 28(1 Suppl):S43-48.

14. Fontaine O, Kosek M, Bhatnagar S, Boschi-Pinto C, Chan KY, Duggan C, Martinez H, Ribeiro H, Rollins NC, Salam MA, Santosham M, Snyder JD, Tsai AC, Vargas B, Rudan I: Setting research priorities to reduce global mortality from childhood diarrhoea by 2015. PLoS Med 2009, 6(3):e41.

15. Kapiriri L, Tomlinson M, Chopra M, El Arifeen S, Black RE, Rudan I: Setting priorities in global child health research investments: addressing values of stakeholders. Croat Med J 2007, 48(5):618-627. 
16. Tomlinson M, Chopra M, Sanders D, Bradshaw D, Hendricks M, Greenfield D, Black RE, El Arifeen S, Rudan I: Setting priorities in child health research investments for South Africa. PLoS Med 2007, 4(8):e259.

17. Tomlinson M, Rudan I, Saxena S, Swartz L, Tsai AC, Patel V: Setting priorities for global mental health research. Bull World Health Organ 2009, 87(6):438-446.

18. Tomlinson M, Swartz L, Officer A, Chan KY, Rudan I, Saxena S: Research priorities for health of people with disabilities: an expert opinion exercise. Lancet 2009, 374(9704):1857-1862.

19. Murata Y: Respiratory syncytial virus vaccine development. Clin Lab Med 2009, 29(4):725-739.

20. Collins PL, Murphy BR: New generation live vaccines against human respiratory syncytial virus designed by reverse genetics. Proc Am Thorac Soc 2005, 2(2):166-173.

21. Progress in Respiratory Virus Vaccine Development: Pathogenesis and Corelates of Immunity. [http://www.medscape.com/viewarticle/558718].

22. Crowe JE: Influence of maternal antibodies on neonatal immunization against respiratory viruses. Clin Infect Dis 2001, 33(10):1720-1727.

23. Meyer G, Deplanche M, Schelcher F: Human and bovine respiratory syncytial virus vaccine research and development. Comp Immunol Microbiol Infect Dis 2008, 31(2-3):191-225.

24. Karron RA, Wright PF, Belshe RB, Thumar B, Casey R, Newman F, Polack FP Randolph VB, Deatly A, Hackell J, Gruber W, Murphy BR, Collins PL: Identification of a Recombinant Live Attenuated Respiratory Syncytial Virus Vaccine Candidate That Is Highly Attenuated in Infants. I Infect Dis 2005, 191(7):1093-1104

25. Wright PF, Karron RA, Madhi SA, Treanor JJ, King JC, O'Shea A, Ikizler MR, Zhu Y, Collins PL, Cutland C, Randolph VB, Deatly AM, Hackell JG, Gruber WC, Murphy BR: The interferon antagonist NS2 protein of respiratory syncytial virus is an important virulence determinant for humans. J Infect Dis 2006, 193(4):573-581.

26. Wright PF, Karron RA, Belshe RB, Thompson J, Crowe JEJ, Boyce TG, Halburnt LL, Reed GW, Whitehead SS, Anderson EL, Wittek AE, Casey R, Eichelberger M, Thumar B, Randolph VB, Udem SA, Chanock RM, Murphy BR: Evaluation of a live, cold-passaged, temperature-sensitive, respiratory syncytial virus vaccine candidate in infancy. J Infect Dis 2000 182(5):1331-1342.

27. Weisman LE: Current respiratory syncytial virus prevention strategies in high-risk infants. Pediatr Int 2002, 44(5):475-480.

28. Healy CM, Baker CJ: Prospects for prevention of childhood infections by maternal immunization. Curr Opin Infect Dis 2006, 19(3):271-276.

29. Stensballe LG, Ravn H, Kristensen K, Agerskov K, Meakins T, Aaby P, Simoes EA: Respiratory syncytial virus neutralizing antibodies in cord blood, respiratory syncytial virus hospitalization, and recurrent wheeze. J Allergy Clin Immunol 2009, 123(2):398-403.

30. Roca A, Abacassamo F, Loscertales MP, Quinto L, Gomez-Olive X, Fenwick F, Saiz JC, Toms G, Alonso PL: Prevalence of respiratory syncytial virus IgG antibodies in infants living in a rural area of Mozambique. J Med Virol 2002, 67(4):616-623.

31. Munoz FM, Piedra PA, Glezen WP: Safety and immunogenicity of respiratory syncytial virus purified fusion protein-2 vaccine in pregnant women. Vaccine 2003, 21(24):3465-3467.

32. Simoes EA, Tan DH, Ohlsson A, Sales V, Wang EE: Respiratory syncytial virus vaccine: a systematic overview with emphasis on respiratory syncytial virus subunit vaccines. Vaccine 2001, 20(5-6):954-960.

33. Glezen WP, Paredes A, Allison JE, Taber $L H$, Frank AL: Risk of respiratory syncytial virus infection for infants from low-income families in relationship to age, sex, ethnic group, and maternal antibody level. J Pediatr 1981, 98(5):708-715.

34. State of the art of new vaccines: Research and development. [http:// www.who.int/vaccine_research/documents/stateoftheart/en/index.html].

35. Groothuis JR, Simoes EA, Levin MJ, Hall CB, Long CE, Rodriguez WJ, Arrobio J, Meissner HC, Fulton DR, Welliver RC, et al: Prophylactic administration of respiratory syncytial virus immune globulin to highrisk infants and young children. The Respiratory Syncytial Virus Immune Globulin Study Group. N Engl J Med 1993, 329(21):1524-1530.

36. The IMpact-RSV Study Group: Palivizumab, a humanized respiratory syncytial virus monoclonal antibody, reduces hospitalization from respiratory syncytial virus infection in high-risk infants. The IMpact-rSV Study Group. Pediatrics 1998, 102(3 Pt 1):531-537.
37. Carbonell-Estrany $X$, Simoes EA, Dagan R, Hall CB, Harris B, Hultquist M, Connor EM, Losonsky GA: Motavizumab for prophylaxis of respiratory syncytial virus in high-risk children: a noninferiority trial. Pediatrics 2010, 125(1):e35-51.

38. Storey S: Respiratory syncytial virus market. Nat Rev Drug Discov 2010, 9(1):15-16.

39. Piedra PA: Clinical experience with respiratory syncytial virus vaccines. Pediatr Infect Dis J 2003, 22(2 Suppl):S94-99.

40. Glezen WP, Taber LH, Frank AL, Kasel JA: Risk of primary infection and reinfection with respiratory syncytial virus. Am J Dis Child 1986, 140(6):543-546.

41. Glezen WP: Respiratory syncytial virus: back to basics. J Allergy Clin Immunol 2009, 123(2):404-405.

42. Gomez M, Mufson MA, Dubovsky F, Knightly C, Zeng W, Losonsky G: Phase-I study MEDI-534, of a live, attenuated intranasal vaccine against respiratory syncytial virus and parainfluenza-3 virus in seropositive children. Pediatr Infect Dis J 2009, 28(7):655-658.

43. Tang RS, Spaete RR, Thompson MW, MacPhail M, Guzzetta JM, Ryan PC, Reisinger K, Chandler P, Hilty M, Walker RE, Gomez MM, Losonsky GA: Development of a PIV-vectored RSV vaccine: preclinical evaluation of safety, toxicity, and enhanced disease and initial clinical testing in healthy adults. Vaccine 2008, 26(50):6373-6382.

44. Schickli JH, Dubovsky F, Tang RS: Challenges in developing a pediatric RSV vaccine. Hum Vaccin 2009, 5(9):582-591.

45. Kim S, Jang JE, Yu JR, Chang J: Single mucosal immunization of recombinant adenovirus-based vaccine expressing F1 protein fragment induces protective mucosal immunity against respiratory syncytial virus infection. Vaccine 2010, 28(22):3801-3808.

46. Hsu KH, Lubeck MD, Davis AR, Bhat RA, Selling BH, Bhat BM, Mizutani S, Murphy BR, Collins PL, Chanock RM, et al: Immunogenicity of recombinant adenovirus-respiratory syncytial virus vaccines with adenovirus types 4 , 5, and 7 vectors in dogs and a chimpanzee. J Infect Dis 1992, 166(4):769-775.

47. Takimoto T, Hurwitz JL, Zhan X, Krishnamurthy S, Prouser C, Brown B, Coleclough C, Boyd K, Scroggs RA, Portner A, Slobod KS: Recombinant Sendai virus as a novel vaccine candidate for respiratory syncytial virus. Viral Immunol 2005, 18(2):255-266.

48. Takimoto T, Hurwitz JL, Coleclough C, Prouser C, Krishnamurthy S, Zhan X, Boyd K, Scroggs RA, Brown B, Nagai Y, Portner A, Slobod KS: Recombinant Sendai virus expressing the $G$ glycoprotein of respiratory syncytial virus (RSV) elicits immune protection against RSV. J Virol 2004, 78(11):6043-6047.

49. Martinez-Sobrido L, Gitiban N, Fernandez-Sesma A, Cros J, Mertz SE, Jewell NA, Hammond S, Flano E, Durbin RK, Garcia-Sastre A, Durbin JE: Protection against respiratory syncytial virus by a recombinant Newcastle disease virus vector. J Virol 2006, 80(3):1130-1139.

50. Collins PL, Purcell RH, London WT, Lawrence LA, Chanock RM, Murphy BR: Evaluation in chimpanzees of vaccinia virus recombinants that express the surface glycoproteins of human respiratory syncytial virus. Vaccine 1990, 8(2):164-168

51. Mok H, Lee S, Utley TJ, Shepherd BE, Polosukhin W, Collier ML, Davis NL, Johnston RE, Crowe JE: Venezuelan equine encephalitis virus replicon particles encoding respiratory syncytial virus surface glycoproteins induce protective mucosal responses in mice and cotton rats. J Virol 2007, 81(24):13710-13722.

52. Fu YH, He JS, Wang XB, Zheng $X X$, Wu $Q$, Xie $C$, Zhang $M$, Wei $W$, Tang $\mathrm{O}$ Song JD, Qu JG, Hong T: A prime-boost vaccination strategy using attenuated Salmonella typhimurium and a replication-deficient recombinant adenovirus vector elicits protective immunity against human respiratory syncytial virus. Biochem Biophys Res Commun 2010, 395(1):87-92.

53. Murawski MR, McGinnes LW, Finberg RW, Kurt-Jones EA, Massare MJ, Smith G, Heaton PM, Fraire AE, Morrison TG: Newcastle disease virus-like particles containing respiratory syncytial virus $G$ protein induced protection in BALB/c mice, with no evidence of immunopathology. $J$ Virol 2009, 84(2):1110-1123.

54. Duffy PE: Maternal immunization and malaria in pregnancy. Vaccine 2003, 21(24):3358-3361.

55. Simoes EA: Immunoprophylaxis of respiratory syncytial virus: global experience. Respir Res 2002, 3(Suppl 1):S26-33. 
56. Routine EPI activities. [http://www.who.int/countries/eth/areas/ immunization/routine/en/index3.html].

57. Nokes DJ: Respiratory syncytial virus disease burden in the developing world. Amsterdam: Elsevier; 2007.

58. Danzon PM, Towse A: Differential pricing for pharmaceuticals: reconciling access, R\&D and patents. Int J Health Care Finance Econ 2003, 3(3):183-205.

59. Salo H, Kilpi T, Sintonen H, Linna M, Peltola V, Heikkinen T: Costeffectiveness of influenza vaccination of healthy children. Vaccine 2006, 24(23):4934-4941.

60. Nair H, Campbell H, Edinburgh Flu Study Group: Global incidence of severe acute lower respiratory infections due to seasonal influenza in young children: a systematic review and meta-analyses. International Conference on Emerging Infectious Diseases: 2010; Atlanta GA American Society for Microbiology; 2010.

61. Greenwood B: Maternal immunisation in developing countries. Vaccine 2003, 21(24):3436-3441

62. Maternal and neonatal tetanus elimination by 2005: strategies for achieving and maintaining elimination. [http://www.who.int/ vaccinesdocuments/DocsPDF02/www692.pdf.].

63. Weber MW, Mulholland EK, Greenwood BM: Respiratory syncytial virus infection in tropical and developing countries. Trop Med Int Health 1998 3(4):268-280.

64. Omer SB, Sutanto A, Sarwo H, Linehan M, Djelantik IG, Mercer D, Moniaga V, Moulton LH, Widjaya A, Muljati P, Gessner BD, Steinhoff M: Climatic, temporal, and geographic characteristics of respiratory syncytial virus disease in a tropical island population. Epidemiol Infect 2008, 136(10):1319-1327.

65. Palivizumab (product information). GaithersburgMD:Medlmmunelnc.; 1998.

66. Kamal-Bahl S, Doshi J, Campbell J: Economic analyses of respiratory syncytial virus immunoprophylaxis in high-risk infants: a systematic review. Arch Pediatr Adolesc Med 2002, 156(10):1034-1041.

67. Whitehall JS, Boilsetty S, Whitehall P, Francis F, Norton R, Patole SK: High Rate of Indigenous Bronchiolitis and Palivuzumab. J Paediatr Child Health 2001, 37(4):416-417.

68. Farina D, Rodriguez S, Bauer G, Novali L, Bouzas L, Gonzalez H, Gilli C, Laffaire E: Respiratory syncytial virus prophylaxis: cost-effective analysis in Argentina. Pediatr Infect Dis J 2002, 21(4):287-291.

69. Chan P, Abdel-Latif M: Cost of hospitalization for respiratory syncytial virus chest infection and implications for passive immunization strategies in a developing nation. Acta Paediatr 2003, 92(4):481-485.

70. Victora CG, Fenn B, Bryce J, Kirkwood BR: Co-coverage of preventive interventions and implications for child-survival strategies: evidence from national surveys. Lancet 2005, 366(9495):1460-1466.

71. Boerma JT, Bryce J, Kinfu Y, Axelson H, Victora CG: Mind the gap: equity and trends in coverage of maternal, newborn, and child health services in 54 Countdown countries. Lancet 2008, 371(9620):1259-1267.

72. Gwatkin DR, Bhuiya A, Victora CG: Making health systems more equitable. Lancet 2004, 364(9441):1273-1280.

73. Victora CG, Hanson K, Bryce J, Vaughan JP: Achieving universal coverage with health interventions. Lancet 2004, 364(9444):1541-1548.

74. Jones B, Zhan X, Mishin V, Slobod KS, Surman S, Russell CJ, Portner A, Hurwitz JL: Human PIV-2 recombinant Sendai virus (rSeV) elicits durable immunity and combines with two additional $\mathrm{rSeVs}$ to protect against hPIV-1, hPIV-2, hPIV-3, and RSV. Vaccine 2009, 27(12):1848-1857.

75. The Jordan Report 20th Anniversary: accelerated development of vaccines 2002. [http://www.niaid.nih.gov/topics/Malaria/Documents/ jordan20_2002.pdf].

76. The Jordan Report: accelerated development of vaccines 2007. [http:// www.niaid.nih.gov/about/organization/dmid/Documents/jordan2007.pdf].

77. Reduction of respiratory syncytial virus hospitalization among premature infants and infants with bronchopulmonary dysplasia using respiratory syncytial virus immune globulin prophylaxis. The PREVENT Study Group. Pediatrics 1997, 99(1):93-99.

78. Groothuis JR, Simoes EA, Levin MJ, Hall CB, Long CE, Rodriguez WJ, Arrobio J, Meissner HC, Fulton DR, Welliver RC, et al: Prophylactic administration of respiratory syncytial virus immune globulin to highrisk infants and young children. The Respiratory Syncytial Virus Immune Globulin Study Group. N Engl J Med 1993, 329(21):1524-1530.
doi:10.1186/1471-2458-11-S3-S30

Cite this article as: Nair et al:: An evaluation of the emerging interventions against Respiratory Syncytial Virus (RSV)-associated acute lower respiratory infections in children. BMC Public Health 2011 11(Suppl 3):S30.

\section{Submit your next manuscript to BioMed Central and take full advantage of:}

- Convenient online submission

- Thorough peer review

- No space constraints or color figure charges

- Immediate publication on acceptance

- Inclusion in PubMed, CAS, Scopus and Google Scholar

- Research which is freely available for redistribution 